\title{
Lumen
}

Selected Proceedings from the Canadian Society for Eighteenth-Century Studies

\section{Victuallers and Social Mobility: Some Implications of Fielding's Providential Design}

\section{Kathleen Barnett}

\section{Volume 15, 1996}

URI : https://id.erudit.org/iderudit/1012469ar

DOI : https://doi.org/10.7202/1012469ar

Aller au sommaire du numéro

\section{Éditeur(s)}

Canadian Society for Eighteenth-Century Studies / Société canadienne d'étude du dix-huitième siècle

ISSN

1209-3696 (imprimé)

1927-8284 (numérique)

Découvrir la revue

Citer cet article

Barnett, K. (1996). Victuallers and Social Mobility: Some Implications of

Fielding's Providential Design. Lumen, 15, 1-15.

https://doi.org/10.7202/1012469ar 


\title{
1. Victuallers and Social Mobility: Some Implications of Fielding's Providential Design
}

\author{
... Some landladys have got the gout, \\ They scarce can turn their arms about, \\ They are so lazy, and so fat, \\ Their money is so easily got...
}

('Tobie's Experience Explain'd')

'An Author ought to consider himself,' begins the narrator of Tom Jones, 'as one who keeps a public Ordinary, at which all Persons are welcome for their Money' (31). He promises to act the part of an 'honest Victualler' and to provide 'not only a general Bill of Fare to our whole Entertainment, but ... particular Bills to every Course which is to be served up in this and the ensuing Volumes' (32). Yet this sort of 'honest and wellmeaning Host' upon whom Henry Fielding models his narrator is conspicuously absent among the numerous innkeepers and publicans who tend the ordinaries in Joseph Andrews and Tom Jones. While the narrator both welcomes to his literary feast all those who savour his Bills of Fare and anticipates the gratification of his guests as they travel through his fictional world, the victuallers who inhabit that world rarely display such genuine hospitality or deference. ${ }^{1}$

Although Fielding could not have known he lived during the historical prelude to secularization - as we understand it with hindsight today - or that social upheaval was impending, he was nevertheless clearly sensitive to the effects of this period of transition in England. His reply is audible in his novels. The unease with which Fielding viewed the emerging social mobility within his society's traditionally rigid hierarchical system surfaces in both Joseph Andrews and Tom Jones in his renderings of the underclasses. The victuallers embody one example of this anxiety in his fiction. The homogeneity of his unfavourable portraits of the profession consistently insinuates an unscrupulousness inherent in their endeavours to improve their financial and social status. The relentless consistency with which Fielding presents the victuallers as grasping and mercenary materialists suggests an insistent determination 
on his part to disparage the notion of social mobility. Fielding thus prompts a disapproving glance toward their attempts at realizing independent livings. In doing so, he ultimately reveals his own disquiet over the unprecedented numbers of the populace who seemed to be testing the once inflexible class boundaries.

By the time Fielding wrote Joseph Andrews and Tom Jones there was already widespread antipathy toward the swelling numbers who had entered the victualling occupation since the late seventeenth century. Writings from the period abound with images of unprincipled victuallers who had left their original social stations in a parasitic quest for profit and social elevation. The cynical stereotype already established in popular culture provided Fielding a ready type that he could embellish in the novels.

The stereotype evolved with the recent and conspicuous expansion of this entrepreneurial group, an expansion that coincided with the increased travel between London and the surrounding countryside: improved roads, escalating migration to the city, and more frequent pleasure excursions to the country necessitated a greater number of roadside public houses. ${ }^{2}$ There were changes in the nature of the occupation itself that prompted further notice. Peter Clark points out that victuallers were 'evincing a more commercial approach to their business'; many who chose to enter the trade did so not merely to support themselves, but for the purpose of profit (195). As improvements were made to attract customers in an increasingly competitive market and as many victuallers attempted to cater toward the tastes of a more elite clientele, the public houses gained a new-found respectability. Successful victuallers, particularly innkeepers, quickly gained an enhanced social status (Clark 195, 202-05, 285).

Animosity toward the occupation, such as that articulated above in 'Tobie's Experience Explain'd,' grew with the victuallers' increasingly commercial business strategies. The ballad proceeds to disparage 'those lazy queens' of recent prosperity who callously cajole the underclasses into wasting their hard-earned money:

... A labouring man must work all day,

For meat and one poor sixpence pay,

If in an Ale house once he went,

How quickly is that sixpence spent...

This, however, was not the only complaint. Ned Ward, for example, contends that the majority of victuallers were not only avaricious, but boorish: 
Some few indeed there are who, having the advantage of an education above the employment they have taken upon 'em, know how to treat everybody with such a proportion of respect as is due to their quality or appearance. These, being of another mould, are generous and obliging, and quite the opposite to that mercenary, brutish temper with which most of 'em are possessed, either by nature or acquirement. ([my emphasis] 257)

The stereotype was a common one: members of the trade were frequently depicted as money-grubbing oafs who did not know their place.

A further objection, one that was voiced in more subdued tones partly because it did not easily lend itself to raillery and partly because it divulged anxious indignation - was expressed by those who would protect a status quo that restricted social mobility. Since the victualling occupation had been swelling for decades, it was apparent that its members were vacating other positions to fill the new demand: The Publick-Housekeeper's Monitor, for example, describes the victuallers as having left 'their proper Callings in which they were bred up' ([my emphasis] 27). In a society that traditionally espoused an inflexible social order, the victuallers' attempts at financial gains and social ascent threatened the established social hierarchy: such aspirations from below required the abandonment of a 'proper Calling' in order to gain improved status; such ambitions further implied, by extension, that inherited social rank - so intrinsic to the maintenance of the hierarchical system - was somewhat inconsequential.

While derisive portraits of victuallers are typically caricatures and comic stereotypes, they nevertheless often intimate latent apprehensions on the parts of their authors: the victuallers' apparent indifference toward traditionally fixed social ranks was considered by some symptomatic of a more pervasive threat. Ward's comments suggest such an anxiety:

as soon as a tradesman has got a little money by the business he was bred to, observing the lordliness of victuallers, the laziness of their lives, the plentitude of their purses and welfare of their families, he resolves to thrive upon his own small stock at the same rate and pursue the hopes and prospect of growing rich with the same expedition. Accordingly he takes a house well situated for his purpose where in a few years time, behaving himself at first very humble, he advances himself to some petty office of the parish with which he begins to swell and look as stiff and as wealthy as an alderman after knighthood. ([my emphasis] 257)

In an increasingly mercantile society, victuallers were not the only people testing the rigidity of the social hierarchy's previously uncompromising and fixed stratifications. A new flexibility within the social 
system facilitated the potential for some advancement at every level. Those who managed to succeed in bettering themselves (financially and therefore socially) were soon forgetting or ignoring the providentialist teachings of their conservative clergymen, who insisted upon contentment within the pre-ordained stations of the social hierarchy and that one's lot was decreed for an unknowable, but benevolent purpose. A backlash resulted. Indeed, Fielding's era was inundated with multiple pamphlets and tracts stressing the duty of submission to station. ${ }^{3}$ Virtually all of these tracts were directed toward the underclasses, particularly occupational groups such as servants and victuallers who were in close proximity to the upper classes and might thus be tempted to resent the striking disparity between their own lot and that of those they served. Social ambitions, the tracts underscored, were a pretentious and impious challenge to divine will.

Consequently, providentialist tenets helped keep the status quo in place, providing a convenient means for the championing of a system that protected hegemonic privileges, political, economic, and social. Any apparent resistance to hierarchical stratifications could be branded a pretentious affront to the divinely-imposed stratifications in the Great Chain of Being: as Alexander Pope wrote, 'Where, one step broken, the great scale's destroyed' (An Essay on Man I. 244)

Accordingly, when re-thinking Fielding's methodology in Joseph Andrews and Tom Jones, his employment of a mimetic providential design has further implications than once supposed. ${ }^{4}$ Leopold Damrosch Jr. accurately describes this design as one where

[a]n omniscient and affectionate narrator acts as the disposing deity of the fictional universe, instructing the reader, by means of a plot whose coherence is only gradually revealed, to understand the operations of a Providence that subsumes all of the apparent accidents of chance or Fortune. (263)

In other words, as others have argued, the narratives - with their seemingly unjust and chaotic moments, their unusual but timely coincidences, and the ultimate poetic justice that closes them - mirror the contemporary perception of a larger world created and sustained by Providence. However, the mimetic designs do not merely provide the conceptual principle for order and pattern in Fielding's fictional worlds; nor are they simply a convenient device to procure happy endings; nor do they merely furnish a means to reflect the traditional Christian world view. The mimetic designs additionally afford Fielding the means to vindicate social inequalities, to assuage the guilt of those who possessed privilege, and to appease those who did not. 
Included in his design is a mimetic Artificer who dispenses social elevation as the ultimate reward for the meritorious in the conclusions of the novels. Such rewards, however, as Mary Poovey demonstrates, are simply metaphorical ones: they represent the recompense the virtuous will find in the afterlife (314). ${ }^{6}$ But Fielding runs into one difficulty: how to avoid Samuel Richardson's implication in Pamela - one Fielding disdained - that such rewards are possible for the virtuous in the temporal world. ${ }^{7}$ The narrator of Tom Jones articulates the problem:

There are a Set of Religious, or rather Moral Writers, who teach that Virtue is the certain Road to Happiness, and Vice to Misery in this World. A very wholsome and comfortable Doctrine, and to which we have but one Objection, namely, That it is not true. ${ }^{8}(783)$

Fielding finds his solution in birth-mystery plots - no one ascends without prior claim to social rank: it turns out that Tom Jones is not the son of a servant after all, but the nephew of Squire Allworthy; nor is Joseph Andrews actually born to the lowly station of servant, but the long-lost son of the Wilsons. ${ }^{9}$ Accordingly, Fielding's initial challenge to elitist assumptions is misleading. The novels, at first, seem to provide examples of superior goodness from among the lower orders in the characterizations of Tom and Joseph; but the resolutions prove that these anomalous examples are exceptional only because the protagonists never belonged among the lower orders in the first place. Ultimately, the heroes are reinstated to the legitimate social positions from which they were earlier dislocated, indicating Fielding's reluctance to permit the membership of his moral aristocrats among the lower orders and confirming his own allegiance to hierarchical stratifications.

Fielding does not, of course, imply that superior social status corresponds with a superior morality - this would contradict both the reality his readers experienced and the mimetic designs of his novels. Indeed, much of his satire is directed against the vices of the elite. The wicked or corrupt behaviour of the likes of a Lady Booby, Lady Bellaston, or Beau Didapper frequently is set in relief against the good intentions and benevolent dispositions of other characters, particularly the apparently lower-born Joseph and Jones (these contrasts, of course, only seem to imply that the lower orders can outshine their social superiors). But, significantly, the underclasses are not depicted with the same moral diversity: few, if any, legitimate members are portrayed as virtuous. Accordingly, among the lower strata, moral worth does tend to correspond with social worth. Many of the elite may prove unworthy of the wealth, prosperity, and status they enjoy; yet, among the lower orders, 
few, if any, evoke much sympathy - other than Jones and Joseph — for the hardships they endure in their humble stations. ${ }^{10}$

While on the one hand Fielding may employ his aristocratic characterizations to mirror the mysterious Design of Providence in assigning social rank and privilege, simulating the sometimes seeming disorder and unjustness of a world where the corrupt are privileged; on the other, he simultaneously utilizes the lower orders to justify social inequality as being in accordance with and conforming to a more transparent and comprehensible providential will. His inconsistency overtly suggests that the mysteries of apparent injustices are part of the divine scheme (injustices that are mimetically resolved for Joseph and Jones) and covertly suggests a moral disparity between most of the upper echelons and those beneath them. While it is unlikely that Fielding actually believed in these stratified moral distinctions, the intimation nevertheless is a convenient means for his fiction to champion hegemonic interests, and to vindicate the fixedness and rigidity of traditional social order that this hierarchical system required.

Modern criticism does not pretend to accept eighteenth-century depictions of the underclasses as accurate: more often than not, they are distorted peripheral characterizations that provide little more than the illusion of social diversity. Invariably, servant and victualler types furnish this superficial representation of the lower orders. As hollow props of realism, they generally serve in a further limited and secondary capacity as comic figures with stock responses or as foils by which the protagonists' actions can be measured. ${ }^{11}$ But Fielding's fiction employs them with a further rhetorical purpose in mind: relying on his audience's familiarity with popular contemporary images of the unscrupulous victualler, Fielding constructs a homogeneous portrait of the occupation that prompts the illusion of a social threat posed from below.

As Joseph and Jones make their peripatetic ways between their respective estates and London, the roads traversed yield nearly twenty public houses with almost thirty attending victuallers, providing an effective constant for Fielding to develop his homogeneous portrait. An early encounter in Joseph Andrews suggests the victualler prototype. Mrs. Tow-wouse initially refuses to clothe or house the naked and beaten Joseph, fearing that he has no money to pay her. 'Common Charity, a F - $t$ !' is her response (56). Only when the chambermaid persuades her that Joseph may be 'a greater man than they took him for,' and thus able to pay for his food and lodgings, does she offer Joseph clothing and hospitality $(61,66)$. Abruptly, Mrs. Tow-wouse no longer refers to Joseph as a 'Vagabond': the opportunity for profit - the true motive of her supposed charity - immediately transforms him into a 'Christian' and 'gentleman' (66). 
Following a brief sojourn at an alehouse, the next inn at which Joseph and Parson Adams arrive further substantiates the victualler prototype. While the hostess initially exhibits compassion for Joseph (tending his recent 'Contusion'), her husband, who is 'indeed perfect Master of his House' and

who always proportioned his Respect to the Appearance of a Traveller, ... observing his Wife on her knees to a Footman, cried out, without considering his Circumstances, 'What a Pox is the Woman about? why don't you mind the Company in the Coach? Go and ask them what they will have for Dinner?' (118-19)

The host's principal consideration is in attending the wealthy guests. Fielding, however, is quick to subvert the hostess's preliminary exhibition of goodwill. A brawl ensues which brings the hostess to her husband's 'assistance, or rather to revenge the Blow' he received from Parson Adams (119). Comic effect reduces and displaces any positive qualities previously apparent: the narrator amends the hostess's 'assistance' to 'revenge,' the 'Pan full of Hog's-Blood' she 'discharge[s] ... into the Parson's Face' draws into the melée a drunken Mrs. Slipslop, and farce prevails (120). Without the comic effect the reader might be inclined to feel sympathy for the hostess, but the ludicrous images of Adams covered in pig's blood and Slipslop standing 'in Triumph' with her vanquished opponent's tufts of hair in her fist redirect our compassion for the hostess's plight from pity to laughter at the absurdity of the scene.

For further effect - indeed to add insult to injury - the scene is bracketed on one side by a contention regarding who is whose 'Better' and a mock-genteel description of how Adams

dealt [the host] so sound a Compliment over his Face with his Fist, that the Blood immediately gushed out of his Nose in a Stream. The Host being unwilling to be outdone in Courtesy, especially by a Person of Adam's Figure, returned the Favour with so much Gratitude... ([my emphasis] 119)

And on the other side resides the image of those who have witnessed the unrefined behaviour of the combatants (presumably those whose genteel greetings the narrator mimics above), standing aghast:

There happened to be in the Inn at this time, besides the Ladies who arrived in the Stage-Coach, the two Gentlemen who were present at Mr. Tow-wouse's when Joseph was detained. ... There was likewise a Gentleman just returned from his Travels to Italy; all whom the horrid Outcry of Murther, presently brought into 
the Kitchin, where the several Combatants were found in the Postures already described. (120)

These scenes bracketing the brawl serve as comic punctuation to heighten and deflate the social pretensions of the combatants.

Self-interest and social pretensions consistently prompt the victuallers' behaviour throughout Joseph Andrews until Fielding seems to offer an exception at the alehouse in Parson Trulliber's parish. Having taken shelter from a storm, Fanny, Joseph, and Parson Adams are treated very hospitably. When they admit that they are penniless, the hostess politely agrees to give them credit. Yet Fielding refuses to break from his established stereotype: the narrator quickly intervenes to explain that the hostess's beneficence bears direct relation to her belief that Adams is the brother of Trulliber: thus her seeming generous behaviour was motivated merely by her fear of affronting the brother of the man whose 'Option [it is] whether she should ever sell another Mug of Drink' (169). Accordingly, when she discovers the truth, she rescinds her offer, launches into a diatribe, demands payment, and threatens a warrant against her guests. Obviously, we cannot expect the victuallers to subsidize the frequently penniless trio's travel expenditures; but the narrative avoids this issue, instead, pointing to the profit-oriented ethos and synchronous lack of charity among the victuallers. Accordingly, the hostess's change of heart regarding the credit she would have extended underscores her insensitive and distrustful nature, as well as her miserly disposition. Her legitimate business concerns regarding Trulliber (the real villain) and his jurisdiction are virtually irrelevant in the narrative.

Every encounter with victuallers in the novel suggests the same universal self-seeking motives for behaviour. And Tom Jones has no better luck in his travels. His first encounter with a landlord likewise inaugurates what will become a succession of similar victuallers. When Robin discovers that Tom 'is but a poor Parish Bastard,' he spends the entire night spying on the sleeping Tom, fearing he might steal something (365-66). Apparently Robin had a silver spoon stolen a year ago. The loss indicates the victualler's vulnerability to pilferers, but the object of his concern is made to seem so trifling that Robin's anxiety translates into an acute paranoia (especially when we know that the hero is not about to steal anything). Fielding circumvents any serious consideration of the rampant property theft in public houses; instead, comic reduction ensures that Robin's earlier loss seems inconsequential and Robin suspicious, petty, and parsimonious. ${ }^{12}$

Robin's opinion of Tom improves when it becomes apparent that Tom has both money and a generous pocket (367). Like Mrs. Tow-wouse, who couples remuneration with being a Christian and a gentleman, Robin 
also believes that money can raise one's status. Both responses suggest that their conception of hierarchical order is a flexible one: if money can make (albeit for a moment) a 'poor Parish Bastard' a gentleman, and a 'Vagabond' a Christian, capital should similarly allow victuallers a corresponding dexterity on the social ladder. Fielding's sardonic portrayal of the victuallers, however, prevents the reader from seriously considering this bourgeois supposition as a viable alternative to the traditionally uncompromising hierarchical order.

Later, the landlady at Hambrook has difficulty discerning Tom's social status because a brawl has left his laced waistcoat obscured by blood. Her assessment of his rank vacillates several times during his period of recovery at the inn, and her hospitality wavers correlatively. When she discovers that he is 'base-born,' and therefore not likely able to afford the repasts or reward her for her attention, Tom soon finds himself removed to the inn's worst room, his medical care discontinued, and his requests for dinner ignored (410-16). However, when she receives subsequent information regarding Tom's close ties to Squire Allworthy, the report provokes a reappraisal of Tom's status and earns him better hospitality (417). It also earns him an exorbitant bill, once it appears he can afford the higher reckoning (429). In a rare direct comment on the trade, the narrator explains the discrepancy in Tom's reckoning:

here we are obliged to disclose some Maxims, which Publicans hold to be the grand Mysteries of their Trade. The first is, if they have any Thing good in their House (which indeed very seldom happens) to produce it only to Persons who travel with great Equipages. Secondly, To charge the same for the very worst Provisions, as if they were the best. And, lastly, if any of their Guests call but for little, to make them pay a double Price for every Thing they have; so that the Amount by the Head may be much the same. (429)

In describing these 'grand Mysteries of their Trade,' Fielding is of course stoking the fears of those who viewed with scepticism the recent commercial prosperity of public houses and is suggesting a conspiracy. The narrator's generalizations here soon prove true in numerous instances of victuallers defrauding and cheating their customers.

Perhaps aware that his portraits of the victuallers tend to blur into a single characterization, Fielding, at one point, has his narrator caution the reader not to find

too near a Resemblance between certain Characters here introduced; as for Instance, between the Landlady who appears in the Seventh Book [Hambrook] and her introduced in the Ninth [Upton]. Thou art to know, Friend, that there 
are certain Characteristics, in which most Individuals of every Profession and Occupation agree. To be able to preserve these characteristics, and at the same Time to diversify their Operations, is one Talent of a good Writer. (525)

Accordingly, when the landlady at Upton is introduced, she maintains the 'certain Characteristics' of her occupation - self-interest and greed - but her 'Operation' is diversified: we are told that she manages a 'House of exceeding good repute' (500), but it is soon apparent that her strict discrimination between virtuous and wicked customers is merely a pretence to discriminate between those who can pay the highest prices and those who cannot. She would have thrown Tom and the ragged Mrs. Waters off the premises had she not overheard a soldier refer to Mrs. Waters as 'her Ladyship' (506). The landlady's' previous indignation directly turns to obsequiousness. Her hypocrisy is further underscored when Susan the chambermaid finds Tom in Mrs. Waters' bed. The landlady insists that Susan must be mistaken: 'no Vagabonds, nor wicked beggarly People come here'; Susan should not believe her 'own Eyes against such good Gentlefolks' who have ordered such a great supper (533-34). Fielding may diversify her 'Operation,' but her pretence to moral standards is nevertheless exposed as the same desire for profit that motivates the other victuallers.

Fielding's narrator explains the 'in our general Descriptions, we mean not Universals, but would be understood with many Exceptions' (JA 190). Yet almost every encounter suggests that the victuallers are all of the same ilk. Fielding may introduce business dilemmas such as vulnerability to theft, the problem of vagrants, and the need to maintain a reputable house, and he may permit his victuallers to rationalise their subsequent responses to these legitimate business concerns; but he consistently translates such instances of economic vulnerability into satiric episodes, and he invariably adds narrative commentary that diminishes, discounts, or discredits his victuallers' expressions of economic vulnerability. Thus he reduces all motives for behaviour to a profit-oriented ethos and condemns the victuallers as dispassionate mercenaries.

Consequently, when any of his victuallers is not typically avaricious or hard-hearted, it is difficult not to question the rhetorical purpose of their place in the narrative. Timotheus provides Joseph shelter during a storm, without receiving remuneration and without any narrative commentary implying ulterior motives (50); and Mrs. Whitefield turns Tom away from her inn, but not before the narrator makes an unprecedented, lengthy, and convincing defense of her motives (434-35). Both of these examples are comparatively brief and both are anomalous instances among the victuallers: the first is a neutral portrait, and the second a 
positive contrast to the hypocritical landlady at Upton. These anomalies also happen to be the only two characterizations based upon genuine victuallers, one in each novel: Timothy Harris (JA 50n1, TJ 432n1) and Elizabeth Whitefield (TJ 430n1). Although the narrator elsewhere inveighs against 'puffs' (TJ 705), these two portraits are exactly that.

Perhaps most telling are Fielding's only other aberrant characterizations; again, one in each novel. The brief appearance of the a kindly 'Sea-faring' host is a memorable one, particularly because - in contrast to the hostess in Trulliber's parish - he trusts the penniless Parson Adams with an outstanding tavern tab, and even offers another pot of ale on the house (177). Fielding not only makes a point of emphasizing that this generous victualler is of considerable abilities and independence, but - more consequential to Fielding's defense of the status $q u o$ - that the benevolent 'Sea-faring' host has been reduced in status and fallen upon hard times (179). He is as anomalous as Joseph among the servants, and for the same reason: his original pre-ordained station is above that in which he serves. Hence, he is yet another moral aristocrat whom Fielding extricates from the lower orders.

The second aberration is Mrs. Miller. Her significance to the plot permits Fielding to place protracted emphasis on her exceptional conduct that sets her apart from the rest of the trade, thus marking the pervasiveness of her antitheses who inundate the novels. She is as anomalous as Tom, and, again, for a similar reason: her status as a landlady is below that to which she was originally and providentially designated: she was 'born and bred a Gentlewoman' (757). It comes as no surprise, therefore, that as the novel closes, she is elevated and reinstated to a superior social position through her daughter's marriage to Nightingale.

Thus the promised 'many Exceptions' in the case of the victuallers are two epigrammatic 'puffs' and two who are born and bred to superior stations - and, of course, the narrator of Tom Jones himself, who postures as an analogous example of an ideal victualler. The remaining members of the occupation - when divested of their comedic roles and separated from those like Tom or Fanny and Joseph, whom John Richetti describes as merely 'playing at being plebeians' (88) - provide a consistently cynical universal portrait of grasping materialists. Relying on contemporary effigies which insinuate that this expanding new breed of victualler is among the growing ranks attempting to permeate stations beyond which they were born, his homogeneous portrait suggests that those who are discontented with their lot will strive to resist their pre-ordained stations by means of a shrewd and unscrupulous accumulation of money. Since the portrait of a character attempting to better his or her life by itself would be insufficient to condemn anyone, Fielding 
repeatedly translates their efforts at self-improvement into social pretensions inspired by greed and worldly ambitions.

Individually, the victuallers exemplify the plethora of instances from among the underclasses who justify a providentially-ordered social inequality; they are aptly confined to the lower strata. But their grasping materialism threatens the divinely-imposed stratifications necessary to workings of the Whole - 'Where, one step broken, the great scale's destroyed' - and by extension the fabric of society. Cumulatively, the victuallers insinuate a coherent and swelling segment of the populace below who were discontent with their lot and resistant to the traditional social order. However, the mimetic Artificer, who ultimately dispenses just rewards and punishments, preserves the status quo. Accordingly, the novels, in their vindication of providentially-imposed stratifications, justify social inequality and attempt to assuage the guilt of the socially elite and to appease the potential resentments of the underclasses - as Pope had argued earlier in An Essay on Man, 'Whatever is, is Right' (II. 294). At the same time, they inadvertently forewarn against the ensuing disintegration of the elite's hegemonic dominion and the impending emergence of a more openly bourgeois society.

\author{
KATHLEEN BARNETT \\ McMaster University
}

\title{
Notes
}

1 I use 'victualler' and 'public house' as generic terms to refer to the landlords, landladies, hosts, and hostesses and the inns, taverns, alehouses that they kept, except where Fielding is specific.

$2 \mathrm{H}$. George Hahn notes that 'general migration was to town, the origin of new money and the seat of opportunity for employment, wealth and power.' London's population increase indicates the influx: the population of 200,000 in 1600 swelled to 675,000 by 1750 . But traffic went both ways as 'canals, better roads, and more comfortable coaches made the countryside accessible for most' $(1,14,16)$. Peter Clark further points out that 'excursions to the countryside came into vogue among the London populace, and in the 1740s it was said that every sixth house in villages close to the capital had facilities for visitors' (200).

3 See, for example, The Publick-Housekeeper's Monitor, Jonas Hanway, Advice from Farmer Trueman to his Daughter Mary: Upon her Going to Service... (n.d.; London, 1810) (the tract was a contemporary one since Hanway lived from 1712 to 1786); Eliza Haywood, A Present for a Servant-Maid (London, 1743) rpt. in 'A Present for Servants, from their Ministers, Masters, Or Other Friends' and 'A Present for a Servant-Maid' (New York: Garland, 1985); Eliza Haywood A Present for Servants, 
from their Ministers, Masters, Or Other Friends (London, 1787) rpt. in 'A Present for Servants, from their Ministers, Masters, Or Other Friends' and 'A Present for a Servant-Maid' (New York: Garland, 1985); Thomas Seaton, The Conduct of Servants in Great Families (London, 1720; New York: Garland, 1985); and John Waugh, The Duty of Apprentices and Other Servants: A Sermon Preach'd... August 24th, 1713 (London, 1713).

4 Martin C. Battestin was the first to note the importance of the mimetic providential design in shaping the narrative of Tom Jones ('Argument'). Aubrey Williams persuasively argues that the design is apparent in Joseph Andrews as well (266).

5 Damrosch recognizes a similar impetus in Fielding's novels (266).

6 See also Brian McCrea's 'Rewriting' (145) and Battestin (316-17).

7 Doody, in her astute discussion of Shamela and Pamela, aptly notes that although 'Fielding denounced Pamela as an affront to literature and to morality, and no doubt he was sincere in thinking this was what he found objectionable... [he] gives himself away [in Shamela] - one realizes that the author belongs to the upper class, and Richardson's novel had aroused a fear of upstarts meddling with their betters' $(72,74)$.

8 Fielding makes an earlier comment in The Champion that is consistent with his narrator's assertion: 'a glorious Consideration to the virtuous Man, is that he may rejoyce even in the never attaining that which he so well deserves, since it furnishes him with a noble Argument for the Certainty of a future State. As it is inconsistent with the Justice of a supremely wise and good Being, to suffer his honest and worthy Endeavours to go unrewarded, can the Heart of Man be warmed with a more ecstatic Imagination, than that the most excellent Attribute of the great Creator of the Universe is concerned in rewarding him?' (4 March 1739/40).

9 McCrea's 'Rewriting' provides a very helpful discussion of the birth-mystery plots.

10 The servants, like the victuallers, have few redeeming qualities. Fielding, for instance, exposes the self-interest and mercenary natures of Slipslop, Honour, Wilkins, and other servants throughout both novels. Less obviously, however, Fielding also undercuts even the most ancillary characters with ostensibly extraneous narrative commentary. For example, when the narrator inserts what at first appears a rather discursive discussion of the kindly Betty's sexual appetite and a chronicle of her previous bed-fellows at the Tow-wouse Inn, the explication offers more than a diverting portrait of a contemporary stereotype. Betty's 'warm Ingredients' are menacing, and not merely because they pose a threat to the comically chaste hero: the narrator's insinuations about venereal disease underscore the potential danger Betty poses to Joseph if he were to succumb to her amorous advances. Indeed, '[o]fficers of the Army, young Gentlemen..., Squires, and some of graver Character,' we learn, were previously 'set afire' before the surgeon could contain the contagion, and Betty continues to 'share her Favours' with 'Tom Whipwell the Stage-Coachman, and now and then a handsome young Traveller' (86-7). Fielding similarly undercuts the postilion's kindness toward Joseph. Like Betty, the postilion assists Joseph - lending him a coat when no one else will (52-3). The brief episode, of course, underscores a moral apathy and lack of compassion among the postilion's social superiors who occupy the coach; but it also separates the postilion from Fielding's other 
underclass portraits because the postilion demonstrates virtues inconsistent with his humble status. The characterization seems to disrupt Fielding's otherwise consistent rhetorical efforts to avoid suggesting that - despite the mysteries of the Design - some of those who occupy society's lower tiers could potentially benefit humanity at a more elevated social level. The postilion's gesture of kindness - performed without anticipation of recompense or personal benefit would seem to distinguish this servant from Fielding's other underclass characterizations and would appear a rare admission on the part of Fielding that, in fact, not all members of the underclasses are marked by an ignoble disposition. But Fielding, uneasy portraying any 'low People' with a disproportionately 'high' moral worth, ultimately complicates his portrait of the postilion and turns this good Samaritan into a thief: the narrator adds, seemingly extraneously, that the postilion 'hath been since transported for robbing a Hen-roost' (53).

11 John Richetti discusses the difficulty in locating sustained representations of the common people in the novels of this period (84-5). See also Bruce Robbins' discussion of the servant's role in Western literature ( $x-x i, 41,76)$.

12 Clark explains that 'alehouses had been a target for criminals since the late seventeenth century.' As a victualler's affluence increased, so did his vulnerability: '[t]hefts of property were endemic - silver cups and spoons, pewter pots, linen, blankets, liquor, tea-kettles and clothes' (289).

\section{Works Cited}

Battestin, Martin C. 'Tom Jones: The Argument of Design.' The Augustan Milieu: Essays Presented to Louis A. Landa. Ed. Henry Knight Miller, et al. Oxford: Clarendon, 1970. 289-319.

Clark, Peter. The English Alehouse: A Social History 1200-1830. London: Longman, 1983.

Damrosch, Leopold Jr. God's Plot and Man's Stories: Studies in the Fictional Imagination from Milton to Fielding. Chicago: U of Chicago P, 1985.

Doody, Margaret Anne. A Natural Passion: A Study of the Novels of Samuel Richardson. Oxford: Clarendon, 1974.

Fielding, Henry. Joseph Andrews. Ed. Martin C. Battestin. Middletown, Conn.: Wesleyan UP, 1967.

The History of Tom Jones, A Foundling. Ed. Fredson Bowers. Middletown, Conn.: Wesleyan UP, 1975.

Hahn, H. George. 'The Country Myth and the Politics of the Early Georgian Novel.' The Country Myth: Motifs in the British Novel from Defoe to Smollett. Ed. H. George Hahn. New York: Lang, 1990. 1-44.

McCrea, Brian. "Had Joseph Not Withheld Himself': The Portrayal of the Social Elite in Joseph Andrews.' God, Man, Nature, and the Enlightenment. Ed. Donald C. Mell. East Lansing: Colleagues P, 1988. 123-28.

'Rewriting Pamela: Social Change and Religious Faith in Joseph Andrews.' Studies in the Novel 16 (1984): 137-49. 
Poovey, Mary. 'Journeys from this World to the Next: The Providential Promise in Clarissa and Tom Jones.' ELH 43 (1976): 300-15.

The Publick-Housekeeper's Monitor. 1730. London, 1781.

Richetti, John. 'Representing an Under Class: Servants and Proletarians in Fielding and Smollett.' The New Eighteenth Century: Theory, Politics, English Literature. Eds. Felicity Nussbaum and Laura Brown. London: Methuen, 1987. 84-98.

Robbins, Bruce. The Servant's Hand: English Fiction From Below. New York: Columbia UP, 1986.

'Tobie's Experience Explain'd.' Roxburghe Collection II. 450. Possibly by Tobias Browne. 1692-93? Rpt. in The Roxburghe Ballads. Vol. 7. New York: AMS, 1966. 153-54.

Turner, E.S. What the Butler Saw: Two hundred and fifty years of the Servant Problem. London: Michael Joseph, 1962.

Ward, Ned. The London Spy. Vol. 15. Ed. Kenneth Fenwick. London: Folio Society, 1955.

Williams, Aubrey. 'Interpositions of Providence and the Design of Fielding's Novels.' South Atlantic Quarterly 70 (1971): 265-86. 